\title{
RESENHA:
}

\section{O “IASB" (JUNTA DE NORMAS INTERNACIONAIS DE CONTABILIDADE) COMO PROPONENTE GLOBAL DE NORMAS CONTÁBEIS}

\section{EL “IASB” (JUNTA DE NORMAS INTERNACIONALES DE CONTABILIDAD) COMO PROPONENTE GLOBAL DE NORMAS CONTABLES}

\author{
L. NELSON CARVALHO \\ Professor, FEA USP, e pesquisador, Fipecafi \\ Presidente, Conselho Consultivo de Normas IASB \\ Inelson@usp.br
}

Entre muitas influências que mostraram a necessidade de normas contábeis globalizadas, três momentos são particularmente marcantes: a crise da Bolsa de Nova lorque em 1929, a desvalorização do dólar no Governo Nixon nos Estados Unidos e o brutal incremento de negociações com valores mobiliários a partir dos anos 90 do século passado.

Efeitos da crise de 1929 na normatização contábil nos EUA: O primeiro episódio - a crise de 29 - nasceu circunscrito a um país, conquanto com efeitos em escala mundial e um extenso inventário de causas responde pela queda violenta nos preços de ações nos Estados Unidos naquele ano. Nenhuma de tais causas é individualmente reconhecida pela literatura acadêmica como principal ou determinante e, sim, como componente de um conjunto perverso de condições que permitiram a destruição de valor de empresas e o caos social que se seguiu. Há problemas identificados na política monetária da época, na gestão dos gastos públicos do Governo, na ausência de agências reguladoras de mercado, no arcaísmo das legislações vigentes para as companhias e as relativas a falências e concordatas, e muitas outras. Uma das causas que permitiram a derrocada do mercado acionário estadonidense na época foi a tibieza das normas contábeis aplicáveis às companhias em geral e às companhias abertas em particular. A reação da sociedade dos Estados Unidos foi intensa e em muitos pontos bastante eficaz; a Lei das S/A daquele país foi reformada, e uma agência para regular e fiscalizar o mercado de valores mobiliários foi criada (a 
"S.E.C", equivalente à CVM brasileira). Os auditores independentes cuidaram de liderar o refazimento das 'frouxas' normas contábeis de então, criando no âmbito de seu instituto profissional não-governamental (o "AICPA", equivalente ao IBRACON do Brasil de hoje) um grupo profissional interdisciplinar de trabalho a que chamaram de "APB", iniciais da expressão em inglês "Junta de Princípios Contábeis". O "APB" emitiu pronunciamentos desde sua criação até os primeiros anos da década de '70. A despeito de grande zelo pela boa técnica e respeito aos fundamentos em seus pronunciamentos, o "APB" carecia de independência, visto formar-se por profissionais vinculados a firmas ou empresas, e ademais sem dedicação exclusiva ao preparo de normas contábeis.

A quebra das paridades cambiais fixas do pós-guerra: Os países do Eixo, derrotados militarmente, dedicaram-se, tanto por vocação (e competência) quanto por estímulo dos vencedores, a reconstruírem suas economias. Detentores de sólidas bases educacionais, reorientaram para fins pacíficos suas bases de produção industrial e em cerca de 25 anos - entre 1945 e 1970 - retomaram elevados patamares de produção, em quantidade e qualidade. No jargão dos economistas, seus PIBs cresceram. Não havia porque se sujeitarem mais à rigidez das paridades cambiais estabelecidas em relação ao dólar, pois eram capazes de exportar e competir em mercados além suas próprias fronteiras. A moeda norteamericana foi desvalorizada; uma versão de câmbio flutuante foi inaugurada; e o paradigma de pujança econômica nacional deixou de ser o padrão-ouro e também o dólar norte-americano: solidez econômica virou função de capacidade nacional de gerar riqueza na forma de produtos e serviços. Abria-se, no início dos anos 70, o caminho para o que viria a ser batizado de 'globalização de mercados', com os detentores de conhecimento e tecnologia passando a olhar outros países não mais apenas como consumidores da produção nacional do Primeiro Mundo, mas como parceiros nessa produção. Fábricas foram "exportadas" das economias desenvolvidas para as emergentes e sinergias foram buscadas em matérias-primas, em recursos naturais ou em mão-de-obra. Economias nacionais emergentes aflorando no mercado produtor, suas empresas depararam-se com o desafio de levantar capitais a custos compatíveis - e na raiz do crédito ou do investimento está a informação, não apenas, mas, principalmente, a informação contábil. Esta é o produto da aplicação de normas às transações, e a soberania de normas domésticas em cada um dos países do mundo levou a uma total incomparabilidade da informação para tomada de decisões econômicas de emprestar ou investir: a linguagem precisava ser "unificada", "harmonizada" ou "globalizada". O risco?: serem os países emergentes forçados a usar normas alienígenas para suas companhias se fazerem entender fora de casa, onde os capitais estavam.

1973 e 1994/95: Os Estados Unidos fizeram em 1973 outra grande "revolução contábil", após o "APB": criaram um organismo normatizador doméstico independente (inclusive do Governo!) e com dedicação exclusiva à tarefa de produzir normas contábeis robustas 


\section{repc}

e consistentes - o "FASB", a Junta de Normas de Contabilidade Financeira'. A este movimento reagiram 10 dos países mais desenvolvidos da época, temendo uma 'imposição indevida' das normas estadonidenses em outras jurisdições pela força (readquirida) da Bolsa de Nova lorque: sendo esta virtualmente o melhor lugar do planeta para empresas levantarem recursos de capital acionário que financiasse seus planos de expansão, e sendo imperativo adotar as normas estadonidenses (os "US GAAP") como pré-condição de ingresso em tal Bolsa, estava armado o cerco para o predomínio dos "US GAAPs" para as "empresas globais" independentemente de seus países de origem. Os referidos 10 países entre os mais desenvolvidos, exceto os EUA, se mobilizaram para criar um organismo que produzisse normas GENUINAMENTE internacionais, no sentido de "supranacionais" ou desvinculadas de influências nacionais de qualquer sorte: nasceu, no mesmo de 1973, o "IASC", Comitê de Normas Internacionais de Contabilidade. Nasceu, porém, sem respaldo oficial: o "FASB" dos EUA tinha por detrás, a conferir-lhe autoridade, a "SEC", agência governamental. O "IASC" não tinha 'padrinhos', apenas a qualidade das normas que produzia. Passaram-se mais de 20 anos nessa situação de isolamento do "IASC"; em 1994, a Organização Internacional das Comissões de Valores (Mobiliários) OICV (sigla em inglês - 'IOSCO') percebeu que investidores domiciliados em um país qualquer compravam seguida e crescentemente, em bolsas de um segundo país, ações de empresas sediadas em um terceiro país - era a globalização dos mercados de capitais. Era necessário regular em que condições tais negócios com ações poderiam e deveriam se realizar, e uma das condições era dada pelas Demonstrações Contábeis disponíveis para a tomada de decisão econômica do investidor - nesse momento, a pseudo-eficácia da Torre de Babel de normas contábeis nacionais soberanas sucumbiu fragorosamente, e ficou clássico o caso da Daymler Benz preparando Demonstrações Contábeis em "US GAAP" e revelando totais de ativos, de exigibilidades, de lucros e patrimônio líquido muito distintos dos preparados originalmente na obediência aos princípios e normas contábeis alemães. As "CVMs", reunidas em seu fórum periódico de discussão - a IOSCO/OICV, entenderam imprescindível consagrar-se normas contábeis internacionais como parte formal do processo de globalização dos mercados de capitais, e o "IASC" teve seu grande momento. No diálogo "IASC" / "IOSCO" entre 1995 - 1999, foi consensada uma filosofia, um propósito e um rumo, e já em 2001 o "IASC" transformou-se em "IASB": foi mais uma mudança de estrutura do que de nome - membros de tempo integral e 100\% independentes foram eleitos para o referido "IASB", e normas internacionais passaram a ser produzidas mediante um 'devido processo', com amplo acesso de TODOS os interessados em reuniões abertas e pela possibilidade de participação em audiências públicas.

HOJE: Mais de 100 dos quase 200 países acreditados perante a ONU ou exigem o preparo de Demonstrações Contábeis consoante as "IFRSs" (as normas emitidas pelo

$1 \quad$ Por "Contabilidade Financeira” entenda-se "Contabilidade Societária" 
"IASB"), ou permitem o uso dessas "IFRSs" a título de substituição das normas nacionais não-revogadas, ou o permitem comparativamente às normas nacionais (tal como é o caso do Novo Mercado, da Bovespa). O Banco Central do Brasil já determinou o uso das "IFRSs" nos balanços dos bancos que publicarem Demonstrações Contábeis em nosso País a partir de 31/12/2010. A CVM já vem, há tempos, direcionando suas orientações contábeis para as Companhias Abertas rumo às "IFRSs". Grandes empresas nacionais já preparam, adicionalmente, Demonstrações Contábeis em "IFRS", ou reconciliam os resultados desses dois conjuntos de normas, o nacional e as "IFRSs". O sonho de 10 idealistas de 1973 é uma indiscutível realidade - mais forte do que pruridos xenófobos mundo afora, normas contábeis internacionais eliminam dificuldades de entendimento de lucros e patrimônios entre fronteiras e viabilizam fluxos de capitais. No mérito, não se discutem normas contábeis: discute-se, a partir delas, redução do custo de capital pelo melhor entendimento do desempenho empresarial. Com maior acesso das boas empresas a crédito e investimentos com menor custo - e tais boas empresas nós as temos, em abundância, no Brasil - discute-se geração de renda e criação de empregos, posto que o empresário competente, passando a ter acesso a tais capitais, construirá mais ativos e produzirá mais. De fato, rumaremos para mais desenvolvimento econômico, para o qual os contabilistas brasileiros têm condições e obrigação de contribuir. 